\title{
Adsorption of Nickel Ions From Aqueaus Solution Using Natural Clay
}

\author{
Mohammed Jaafar Ali Al-atabe \\ Ahmed Alaa Hussein \\ Environmental Eng. Dep., Al-Mustansiriyah University \\ Baghdad, IRAQ \\ mohammedjjafer@uomustansiriyah.edu.iq_ahmedenv83@uomustansiriyah.edu.iq \\ mohammedjjafer@gmail.com \\ Received: 07-March-2017 Revised: 08-Oct.-2017 Accepted: 04-Jan.-2018
}

http://doi.org/10.29194/NJES21020223

\begin{abstract}
The adsorption characteristics of Nickel (II) onto Iraqi Bentonite clay from aqueous solution have been investigated with respect to changes in $\mathrm{pH}$ of solution, adsorbent dosage, contact time and temperature of the solution. The maximum removal efficiency of Nickel (II) ions is $96 \%$ at $\mathrm{pH}=6.5$ and exposure to $100 \mathrm{~g} / \mathrm{L}$ adsorbent. For the adsorption of Nickel (II) ions, the Freundlich isotherm model fitted the equilibrium data better than the Langmuir isotherm model. Experimental data are also evaluated in terms of kinetic characteristics of adsorption and it was found that the adsorption process for $\mathrm{Ni}+2$ ions follows well pseudo-second-order kinetics. Thermodynamic functions, the change of free energy $\left(\Delta \mathrm{G}^{\circ}\right)$, enthalpy $\left(\Delta \mathrm{H}^{\circ}\right)$ and entropy $\left(\Delta \mathrm{S}^{\circ}\right)$ of adsorption are also calculated for Nickel (II) ions. The results show that the adsorption of the Nickel (II) ions on Iraqi Bentonite is feasible and exothermic at (2050) ${ }^{\circ} \mathrm{C}$.
\end{abstract}

Keywords: Adsorption, Nickel (II), Iraqi bentonite clay, Kinetics.

\section{Introduction}

The progressive increase of industrial technology results in a continuous increase of pollution, and a great effort has been devoted to minimize these hazardous pollutants, therefore, avoiding their dangerous effects on animals, plants and humans. Metals can pose health hazards if their concentrations exceed allowable limits. Even when the concentrations of metals do not exceed these limits, there is still a potential for long term contamination, since heavy metals are known to be accumulative within biological systems [1, 2]. Chromium, Nickel, Mercury, Copper, Zinc and Cadmium are frequently detect in industrial wastewaters, which are originate from pesticides, mining activities, battery manufacture, smelting, nuclear industry, metal plating, etc. Over the years some methods have been applied to remove the ions of metal from industrial wastewater and soils. The general traditional methods used for the removal of heavy metal ions from aqueous solutions include: solvent extraction, phyto-extraction, ion-exchange chemical precipitation, and ultra-filtration, reverse osmosis, electro dialysis and adsorption.

Adsorption with low-cost adsorbents has been effectively applied to eliminate heavy metals from contamination solutions [3]. Nickel is a main worry due to its normal use in developing countries with its non-degradable nature .The Nickel persistent toxicity to the environment and humans is also familiar and high Nickel concentrations cause gastrointestinal annoyance, cancers of bone and lung. In recent years, different adsorbents have been used for elimination of Nickel (II) from contaminated solutions [4, 5]. On the other hand, novel adsorbents by local availability, great adsorption capability and economical composed materials are still desirable.

The bentonite clay can be found in many types are following the individual main element; such as calcium (Ca), aluminum (Al), Sodium ( $\mathrm{Na}$ ) and potassium (K). Experts discuss a nomenclatorial problems number in the bentonite clays classifiction. Usually bentonite forms from the volcanic ash weathering, mainly frequently in the presence of water. Bentonite has been widely used as a foundry-sand bond in iron and steel foundries. Bentonites are usually used for decolorizing various mineral, vegetable, and animal oils [6,7]. Bentonite has in adsorbing property and relatively great amounts of protein molecules from contamination solutions. Bentonite is used in a diversity of favorite care things for example it can be used in cat trash to take up the feces contain and odor. It is also used to take up grease and oils.

The objective of the present study is to investigate the adsorption potential of Iraqi Bentonite clay in the removal of $\mathrm{Ni}^{+2}$ ions from aqueous solution. The effects of $\mathrm{pH}$, adsorbent amount, contact time and concentration of metal ions in the solution. The Freundlich and the Langmuir isotherms models are used to explore the equilibrium statistics. In addition, the Nickel(II) ions adsorption mechanisms on the clay are also evaluated within thermodynamics and kinetics conditions. 


\section{Materials and procedure}

\subsection{The Preparation of adsorbent}

From the Geological Survey and Mining Company (Iraq/ Baghdad) were obtain Iraqi bentonite samples. The Iraqi bentonite samples, which were obtained, used with no chemical treatment. The Iraqi bentonite chemical compositions are determined by the X-Ray as shown in Table (1).

Table 1: Chemical composition of I Bentonite Clay (\%).

\begin{tabular}{|c|c|c|c|}
\hline Compound & Mass (\%) & Compound & Mass (\%) \\
\hline $\mathrm{SiO}_{2}$ & 56.9 & $\mathrm{CaO}$ & 1.5 \\
\hline $\mathrm{Al}_{2} \mathrm{O}_{3}$ & 25.0 & $\mathrm{Na}_{2} \mathrm{O}$ & 1.5 \\
\hline $\mathrm{Fe}_{2} \mathrm{O}_{3}$ & 8.9 & $\mathrm{MgO}$ & 1.2 \\
\hline $\mathrm{TiO}_{2}$ & 1.6 & $\mathrm{~K}_{2} \mathrm{O}$ & 1.0 \\
\hline
\end{tabular}

The Iraqi bentonite clay specific surface area is $2.2 \mathrm{~m}^{2} / \mathrm{gm}$. (Table 2). The particle size ranged between 25 and $50 \mu \mathrm{m}$ and its porosity was $75 \%$. Similarly, reported BET surface areas of 1.083 $\mathrm{m}^{2} / \mathrm{g}$ and $2.52 \mathrm{~m}^{2} / \mathrm{g}$ for activated carbon from macadamia nuts used for phenol removal and maize tassels for heavy metal removal from polluted waters, respectively although adsorbents with higher surface areas have been widely reported in literature.

Table 2: Characteristics of Iraqi Bentonite Clay

\begin{tabular}{|l|c|}
\hline \multicolumn{1}{|c|}{ Physical Parameters } & Result \\
\hline BET surface area $\left(\mathrm{m}^{2} / \mathrm{gm}\right)$ & 2.2 \\
\hline Micropore surface ${\text { area }\left(\mathrm{m}^{2} / \mathrm{g}\right)}_{1.25}$ \\
\hline Total pore volume $\left(\mathrm{cm}^{3} / \mathrm{g}\right)$ & 0.02 \\
\hline Micropore volume $\left(\mathrm{cm}^{3} / \mathrm{g}\right)$ & 0.001 \\
\hline Average pore diameter $\left(\right.$ Ao or $\left.10^{-8} \mathrm{~cm}\right)$ & 250 \\
\hline
\end{tabular}

\subsection{Adsorbate solution}

Nickel solution was prepared by using the Nickel sulfate $\left(\mathrm{NiSO}_{4} \cdot 6 \mathrm{H}_{2} \mathrm{O}\right)$ in an analytical mark. The solution of $\mathrm{Ni}^{+2}$ ions was prepared to containing $1000 \mathrm{mg} / \mathrm{l}$ of $\mathrm{Ni}^{+2}$ ions. In the study all solutions prepared by double distilled water.

\subsection{Adsorption Study}

Experiment of adsorption was follow up at the adsorbent dosage level, contact time, and value of desired $\mathrm{pH}$ by the required adsorbent in $500 \mathrm{ml}$ conical flasks containing solutions of Nickel(II) ions in(100 ml). Initial concentrations of metal were $(25,50 \mathrm{and} 75) \mathrm{mg} / \mathrm{l}$. Samples were collected at $(10,20,30,50,70,90,120$ and 140) min to decide the optimal time of shaking. The adjusted values of $\mathrm{pH}$ were $(2,3,4,5,5.5,6,6.5$, 7 , and 8) by using $0.1 \mathrm{M} \mathrm{H}_{2} \mathrm{SO}_{4}$ or $0.1 \mathrm{M} \mathrm{NaOH}$ solution. The adsorbent dosage effect on Nickel(II) removal was studied by using various $\mathrm{Ni}^{+2}$ concentrations in conjunction with $(10,20$, $40,60,80,100,150,180$ and 200) g/L of Iraqi bentonite. The studies of adsorption were also follow up to find out the temperature effect at (20, 30, 40, and 50$)^{\circ} \mathrm{C}$ and to evaluate the thermodynamic parameters of adsorption. Throughout the process of adsorption, flasks were shacked at $200 \mathrm{rpm}$ on a shaker. The flasks content were filtrated throughout filter paper and filtrate was analyzed for the concentration of metal by the Atomic Absorption Spectrometer [AAS]. The amount of $\mathrm{Ni}^{+2}$ absorbed per unit mass of adsorbent (qe) was calculated by the following equation.

$$
\mathrm{qe}=\frac{(\mathrm{Co}-\mathrm{Ce}) \mathrm{V}}{\mathrm{m}}
$$

where $\mathrm{Ci}$ and $\mathrm{Ce}$ represent the initial and equilibrium concentrations of metal ions in aqueous phase. $\mathrm{V}$ is the volume of the solution in liters (l) and $\mathrm{M}$ is the mass of the adsorbent in grams. The metal ions adsorption percentage was calculated by the equation :

$$
\operatorname{Adsorption}(\%)=\frac{[\mathrm{Ci}-\mathrm{Cf}]}{\mathrm{Ci}} \times 100
$$

where $\mathrm{Ci}$ and $\mathrm{Cf}$ are the initial and final metal ion concentrations, respectively. The average absolute value of relative error (AARE) was used to contrast the experimental data with predicted results. That is defined as follows:

$$
\begin{gathered}
\text { AARE }=\frac{1}{\text { NDP }} \\
\sum_{\substack{i=1 \\
\text { in which NDP is the number of data point }[8]}}^{\text {Experimental value }}
\end{gathered}
$$

\section{Result and Discussion \\ 3.1 Adsorbent Dosage Effect}

In adsorption processes, Adsorbent dosage is one of the important parameters because, it's determine the adsorbent capacity for a given adsorbate initial concentration below a given operating conditions set. Figure (1) shows the adsorbent dosage effect on the Nickel(II) ions adsorption. From the figure, it could be noted that there is an increases in the percentage of adsorption when adsorbent dosage increases starting, from 25 to $96 \%$ for $\mathrm{Ni}^{+2}$ ions. The increases of removal efficiency may be attributed to the truth that, an adsorbent dosage increases, a new surface of adsorbent would be available to adsorb the solute [9].

\section{$3.2 \mathrm{pH}$ Effects}

$\mathrm{pH}$ is one of significant parameters that lead to metal ions sorption on different adsorbents is the adsorbate solutions. That is partly because of the nature of hydrogen ion itself as a strong competing sorbate and partially to the truth that the $\mathrm{pH}$ of solution can influence the chemical speciation of metal ions. The $\mathrm{pH}$ effects on nickel 
ions adsorption onto Iraqi bentonite clay is shown in Fig.2. This figure show that at low values of $\mathrm{pH}$, the adsorption efficiency is low; because of increasing in positive charge density(protons) on the clay surface sites, resulting in an electrostatic repulsion among the (Nickel(II) ions and edging groups with positive charge $\left(\mathrm{Si}-\mathrm{OH}^{+2}\right)$ on the surface[10]. When the $\mathrm{pH}$ increases the electrostatic revulsion decreases due to the surface positive charge density is reduction on the sorption ends, therefore on the surface resulting increase in the adsorption of metal ion. Iraqi bentonite surface in an alkaline medium becomes negatively charged. Consistent with Figure (2), the metal ions maximum adsorption occur at $\mathrm{pH}$ 6.5. When values of $(\mathrm{pH} \geq 7)$, the adsorbent capacity was decreased due to metal precipitation and metal ions accumulation. Thus, the best $\mathrm{pH}$ value was 6.5 and this $\mathrm{pH}$ value was selected for the next experiments.

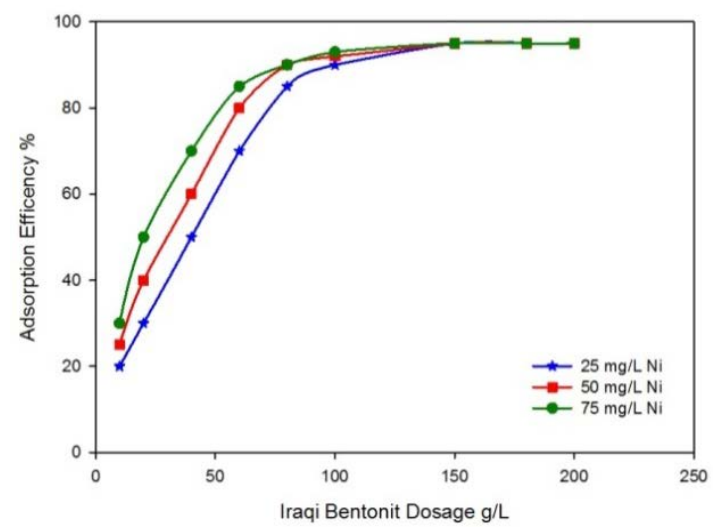

Figure 1: Iraqi Bentonite Dosage effects on the $\mathrm{Ni}^{+2}$ ions adsorption Efficiency in various concentration.

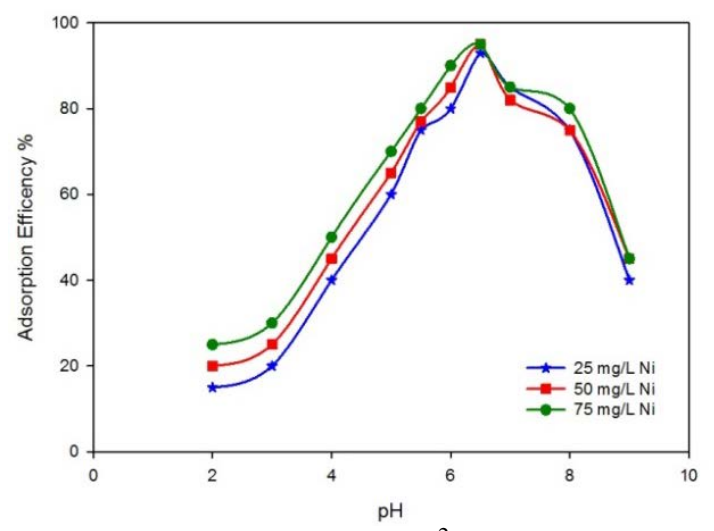

Figure 2: $\mathrm{pH}$ Effects on $\mathrm{Ni}^{+2}$ ions adsorption efficiency \%on Iraqi bentonite various concentration.

\subsection{Shaking Time Effects}

Adsorption of $\mathrm{Ni}^{+2}$ ions on Iraqi bentonite clay in related in to the shaking time is illustrated in Figure (3). From this figure, notes the concentration of Nickel (II) in aqueous solution has rapidly decreased through the first half hour and remained nearly stable after $90 \mathrm{~min}$, signifying that the metal ions adsorption is quick. Thus, $90 \mathrm{~min}$ is selected as the optimum shaking time for $\mathrm{Ni}^{+2}$ ions removal.

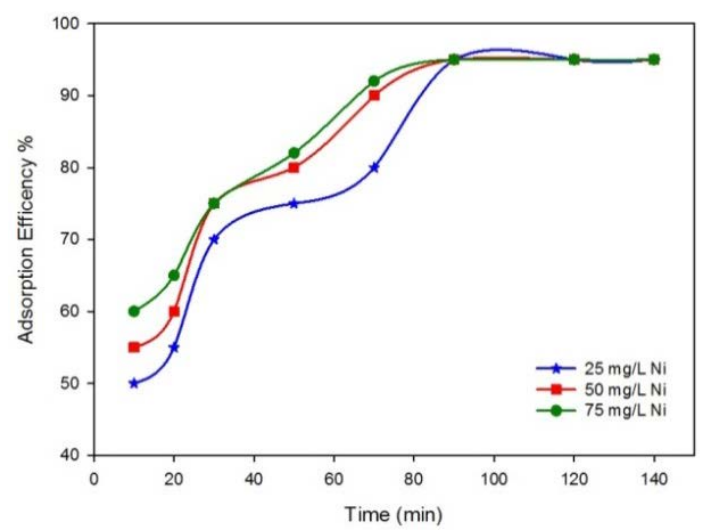

Figure 3: Contact time effect of $\mathrm{Ni}+2$ ions adsorption efficiency \%on Iraqi bentonite in various concentrations.

\subsection{Isotherm Models of Adsorption}

The equilibrium adsorption isotherm can be considered fundamental importance in the adsorption design systems. Langmuir Model is suitable for monolayer adsorption onto a surface containing a limited quantity of the same sites, this model is most frequently used to characterize data on solution adsorption. The adsorption isotherm exact shape for a heterogeneous adsorbent depends on the KL values distribution, and more particularly on the adsorbent regularity distribution of the site adsorption energies [11]. This model can be expressed as:

$$
\begin{aligned}
& \mathrm{q}_{\mathrm{e}}=\frac{\mathrm{qm} \mathrm{KLCe}}{1+\mathrm{KLCe}} \ldots \ldots . . \\
& \text { or } \quad \frac{\mathrm{Ce}}{\mathrm{qe}}=\frac{1}{q m K L}+\frac{C e}{q m}
\end{aligned}
$$

where qe is the equilibrium metal ion concentration on the adsorbent (mg/g), Ce the equilibrium metal ion concentration in the solution (mg/l), qm the monolayer adsorption capacity of the adsorbent (mg/gm) and KL represents the Langmuir adsorption constant $(\mathrm{l} / \mathrm{mg})$, related to the free energy of adsorption. The adsorption type was valid when: (1) the surface of adsorbent is homogeneous; (2) both bulk and surface phases show ideal behavior; and (3) the film of adsorption is monomolecular.

The model of Freundlich [12] is an empirical equation and can be applied for non-ideal sorption on heterogeneous surfaces and multilayer sorption. The equation is commonly given by:

$$
\mathrm{qe}=\mathrm{K}_{\mathrm{L}}\left(\mathrm{C}_{\mathrm{e}}\right)^{1 / \mathrm{n}}
$$

where $\mathrm{KL}$ is a constant related to the adsorption capacity and $1 / \mathrm{n}$ is an empirical parameter related 
to the adsorption intensity, which varies with the heterogeneity of the material.

The Langmuir isotherm non-linearized form was used to get the model constants [13]. The Langmuir model constants are shown in Table (2). The coefficient of correlation $\left(\mathrm{R}^{2}\right)$ was found to be 0.953 for the $\mathrm{Ni}^{+2}$ ions adsorption representing that the model of Langmuir is capable to explain the metal ions adsorption adequately. The maximum capacity value (qm) was found to be $2.24(\mathrm{mg} / \mathrm{g})$ for $\mathrm{Ni}^{+2}$ ions. The $\mathrm{KL}$ value is $1.922(\mathrm{l} / \mathrm{mg})$ for $\mathrm{Ni}^{+2}$ ions.

The isotherm shape can also be considered when predicting whether an adsorption system is "favorable" or "unfavorable". The Langmuir isotherm essential characteristic can be expressed in terms of a dimensionless separation factor or parameter of equilibrium (R) [13], which is defined by the following equation:

$$
R=\frac{1}{1+\mathrm{KLCe}}
$$

According to the value of $\mathrm{R}$, the isotherm shape may be interpreted as described in Table (4). As shown in Table (3), the adsorption of $\mathrm{Ni}^{+2}$ ions onto Iraqi bentonite is favorable. A plot of lnqe vs lnCe enables the empirical constants $\mathrm{KF}$ and $1 / n$ to be determined from the intercept and slope of the linear regression. From Freundlich isotherm obtained by Figure (5) shows plotting $\operatorname{lnCe}$ vs. lnqe values. For the isotherm of Freundlich model the results presents in Table (2) correlation coefficient and constants. For $\mathrm{Ni}^{+2}$ ions $\mathrm{Kf}$ values and $1 / \mathrm{n}$ are set up to be 1.22 and 0.20 . Between 0 to 1 are found $1 / \mathrm{n}$ values, representing that the metal ions adsorption onto Iraqi Bentonite is good in the special operating conditions.

For $\mathrm{Ni}^{+2}$ ions the values of $\mathrm{R}^{2}$ are found to be 0.9657 . The experimental comparison data by qe values obtain from both models are shown in Figures (4) and (5). From these figures, the results of adsorption data obtained are best described with the Freundlich isotherm model.

Table 3: Constants of Langmuir and Freundlich for $\mathrm{Ni}^{+2}$ ions adsorption on Iraqi Bentonite.

\begin{tabular}{|l|c|c|c|c|}
\hline \multirow{2}{*}{$\begin{array}{l}\text { Langmuir } \\
\text { model }\end{array}$} & $\begin{array}{c}\mathrm{qm} \\
(\mathrm{mg} / \mathrm{g})\end{array}$ & $\begin{array}{c}\mathrm{KL} \\
(\mathrm{l} / \mathrm{gm})\end{array}$ & $\mathrm{R}$ & AARD\% \\
\cline { 2 - 5 } & 2.24 & 1.922 & $\begin{array}{l}0.0169 \\
-0.866\end{array}$ & 14.72 \\
\hline $\begin{array}{l}\text { Freundlich } \\
\text { model }\end{array}$ & $1 / \mathrm{n}$ & $\mathrm{Kf}$ & & AARD\% \\
\cline { 2 - 5 } & 0.2 & 1.22 & & 6.42 \\
\hline
\end{tabular}

Table 4: Separation factor for Shape of Isotherm

\begin{tabular}{|c|c|}
\hline Value R & Type of Adsorption \\
\hline $\mathrm{R}>1.0$ & Unfavorable \\
\hline $\mathrm{R}=1.0$ & Linear \\
\hline $0<\mathrm{R}<1.0$ & Favorable \\
\hline $\mathrm{R}=0$ & Irreversible \\
\hline
\end{tabular}

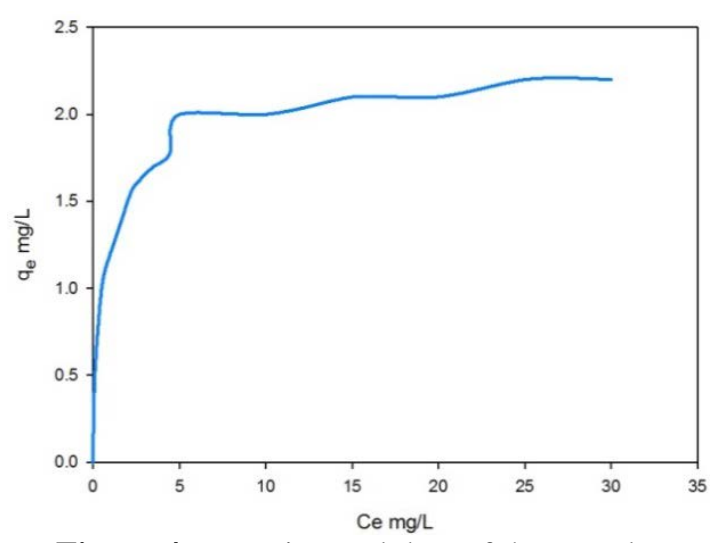

Figure 4: Experimental data of the qe values for $\mathrm{Ni}^{+2}$ ions obtained by Langmuir isotherms.

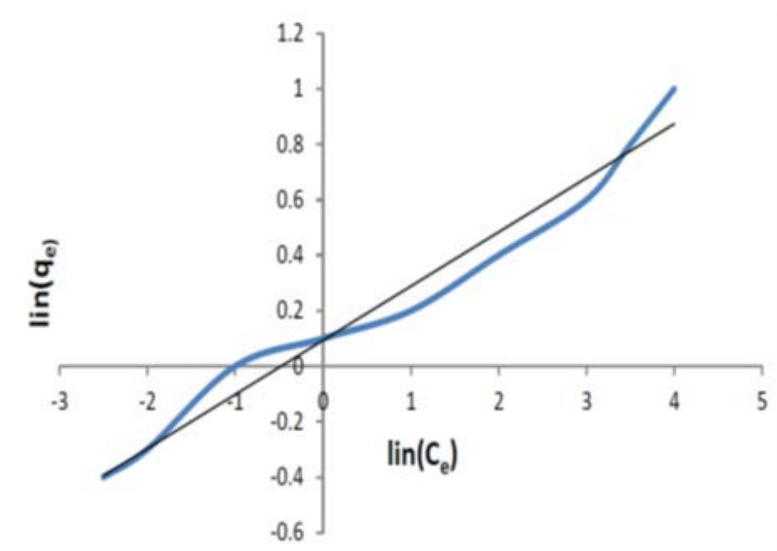

Figure 5: Experimental data of the qe values for $\mathrm{Ni}^{+2}$ ions obtained by Freundlich isotherms.

\subsection{Kinetics of Adsorption}

In order to clarify the $\mathrm{Ni}^{+2}$ ions kinetics of adsorption on Iraqi bentonite Lagergren pseudofirst-order and pseudo-second-order kinetic models are applied to the experimental data. Many researchers have studied the heavy metals kinetics adsorption by using Lagergren pseudofirst-order rate equation [14] and as follows:

$\operatorname{lin}(q e-q t)=\operatorname{linqt}-\mathrm{K}_{1} \mathrm{t}$

where qt $(\mathrm{mg} / \mathrm{g})$ is the amount of the metal ion adsorbed at $\mathrm{t}(\mathrm{min})$ and $\mathrm{k}_{1}$ is the constant rate of the adsorption (min-1). Figure (6) show the Lagergren pseudo-first-order model for the Nickel ions kinetics adsorption on Iraqi Bentonite [15].

Study the heavy metals adsorption kinetics on peat used a pseudo-second-order reaction rate equation. This equation is known in:

$$
\frac{\mathrm{t}}{\mathrm{qt}}=\frac{1}{\mathrm{~K}_{2} \mathrm{qt}^{2}}+\left\{\frac{1}{\mathrm{qe}}\right\} \mathrm{t}
$$

where $k_{2}(\mathrm{~g} / \mathrm{mg} \mathrm{min})$ is the constant rate of the pseudo-second-order equation. This model is more likely to predict the adsorption behavior kinetic by chemical sorption [16].

From this equation the calculated correlation coefficient and the rate constant $\left(\mathrm{k}_{2}\right)$ are listed in Table (5). It's clear from the results that the 
$\mathrm{Ni}^{+2}$ ions adsorption onto Iraqi Bentonite follows well the kinetics of the pseudo-second-order. Ho's pseudo-second-order model is show in Figure (7) for the Nickel (II) ions adsorption kinetics on Iraqi Bentonite.

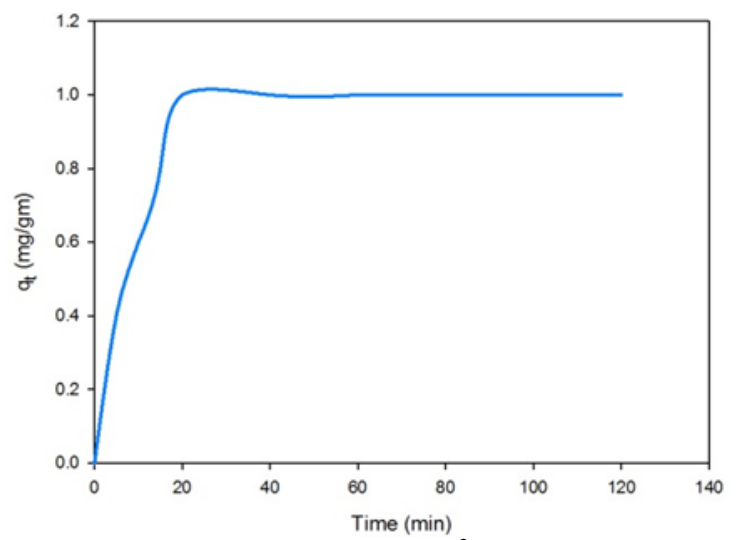

Figure 6: Adsorption of $\mathrm{Ni}^{+2}$ ions on Iraqi Bentonite by The Lagergren Pseudo-first-order model.

The constants of first-order rate from this study with other studies comparison show that the rate of Nickel adsorption on Iraqi bentonite is relatively quick [17].

Table 5: $\mathrm{Ni}^{+2}$ ions Adsorption on to Iraqi Bentonite by Lagergren rate equation constants and Pseudo-second-order rate constant.

\begin{tabular}{|l|c|c|c|}
\hline $\begin{array}{l}\text { Lagergren } \\
\text { rate }\end{array}$ & $\begin{array}{c}\mathrm{K} 1 \\
(1 / \mathrm{min})\end{array}$ & $\mathrm{R}^{2}$ & $\begin{array}{c}\text { AARD } \\
\%\end{array}$ \\
\cline { 2 - 4 } equation & 0.177 & 0.92 & 9.49 \\
\hline $\begin{array}{l}\text { Pseudo- } \\
\text { second- } \\
\text { order rate } \\
\text { equation }\end{array}$ & $\begin{array}{c}\mathrm{K} 2 \\
\text { (gm/mg.min) }\end{array}$ & $\mathrm{R}^{2}$ & $\begin{array}{c}\mathrm{AARD} \\
\%\end{array}$ \\
\cline { 2 - 4 } & 0.193 & 0.991 & 7.60 \\
\hline
\end{tabular}

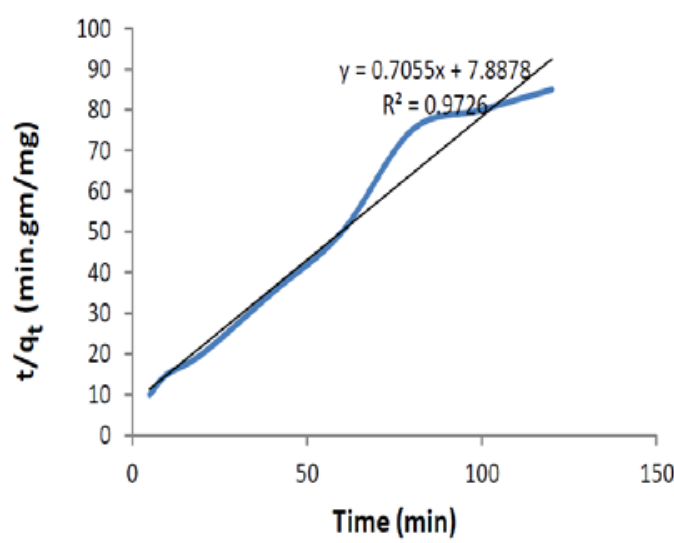

Figure 7: Adsorption of $\mathrm{Ni}^{+2}$ ions on Iraqi Bentonite by model of Ho's Pseudo-Second-order.

\subsection{Adsorption Thermodynamics}

In this study, the range of temperature from (20 to 50) ${ }^{\circ} \mathrm{C}$ was used. The parameters of Thermodynamic, including the free energy changes $\left(\Delta \mathrm{G}^{\circ}\right)$, the enthalpy changes $\left(\Delta \mathrm{H}^{\circ}\right)$ and entropy changes $\left(\Delta \mathrm{S}^{\circ}\right)$, were determined by the following equations [18]:

$$
\begin{aligned}
\Delta \mathrm{G}^{\circ} & =-\mathrm{RT} \text { linKD } . \\
\Delta \mathrm{G}^{\circ} & =\Delta \mathrm{H}^{\circ}-\mathrm{T} \Delta \mathrm{S}^{\circ}
\end{aligned}
$$

where $\mathrm{R}$ is the universal gas constant (8.314 $\mathrm{J} / \mathrm{mol.K}), \mathrm{T}$ is the temperature $(\mathrm{K})$ and $\mathrm{KD}$ is the equilibrium constant. Enthalpy changes $\left(\Delta \mathrm{H}^{\circ}\right)$ and Entropy changes $\left(\Delta S^{\circ}\right)$ of adsorption are obtained from equation below:

$$
\operatorname{linKD}=\left(\Delta \mathrm{S}^{\circ}\right) / \mathrm{R}-\left(\Delta \mathrm{H}^{\circ}\right) / \mathrm{RT}
$$

Consistent with Eq. (10), the parameters $\left(\Delta \mathrm{H}^{\circ}\right.$ and $\Delta \mathrm{S}^{\circ}$ ) can be calculated from the intercept and slope a plot (lnKD vs.1/T), respectively (Figure 8).

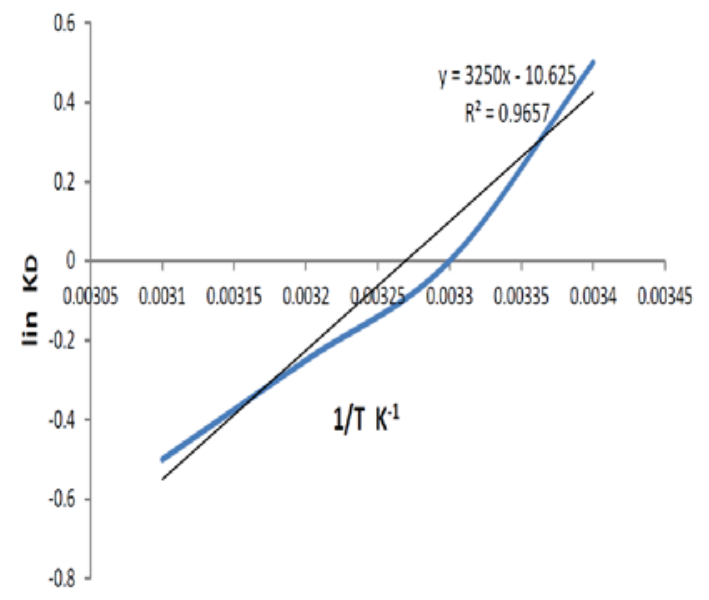

Figure 8: Thermodynamic Parameters for $\mathrm{Ni}^{+2}$ ions Adsorption on Iraqi Bentonite.

To calculated the adsorption Gibbs free energy changes $\left(\Delta G^{\circ}\right)$ from Eq. (8) by calculate $\operatorname{lnKD}$ values for various temperatures. $\Delta \mathrm{G}^{\circ}$ values are set up to be (-1.34, $-0.3,0.62$ and 1.29$) \mathrm{kJ} / \mathrm{mol}$ for $\mathrm{Ni}^{+2}$ ions adsorption at $(20,30,40$ and 50$){ }^{\circ} \mathrm{C}$, respectively.

$\Delta \mathrm{G}^{\circ}$ negative values specify that thermodynamically feasible with the adsorption natural environment of $\mathrm{Ni}^{+2}$ ions at (20 and 30) ${ }^{\circ} \mathrm{C} . \Delta \mathrm{G}^{\circ}$ positive and small values specify that feasible but non-spontaneous process. The value of $\Delta \mathrm{H}^{\circ}$ parameter is $(-26.48 \mathrm{~kJ} / \mathrm{mol})$ for the $\mathrm{Ni}^{+2}$ ions adsorption, That means negative value is specify the $\mathrm{Ni}^{+2}$ ions adsorption is of exothermic nature onto Iraqi Bentonite in the temperature range from $20^{\circ} \mathrm{C}$ to $50^{\circ} \mathrm{C}$. The $\Delta \mathrm{S}^{\circ}$ values are set up to be $(-6.31) \mathrm{J} / \mathrm{mol}$. ${ }^{\circ} \mathrm{K}$ for the $\mathrm{Ni}^{+2}$ ions adsorption. The $\Delta \mathrm{S}^{\circ}$ negative values suggest a reduce in the un-certainty at the solid/solution interface through the $\mathrm{Ni}^{+2}$ ions adsorption on Iraqi Bentonite clay [19]. 


\section{Conclusions}

Nickel (II) ions adsorption behavior on Iraqi bentonite clay was investigated in a group of experiments. There are many parameters that can effect on the adsorption reaction. This was set up to be drastically dependent on adsorbent dosage, contact time, and $\mathrm{pH}$. The $\mathrm{Ni}^{+2}$ ions adsorption speed was rapid. The Nickel-Bentonite system reached to equilibrium within 90min. For $\mathrm{Ni}^{+2}$ ions adsorption state optimum $\mathrm{pH}$ was found to be 6.5. From the data of isotherm analysis it appeared that $\mathrm{Ni}^{+2}$ ions adsorption pattern on Iraqi Bentonite clay was followed the Freundlich model. The Iraqi Bentonite clay greatest capacity was predicted to be $2.24(\mathrm{mg} / \mathrm{g})$ for $\mathrm{Ni}^{+2}$ ions, when the equation of Langmuir model is used. The $\mathrm{Ni}^{+2}$ ions best kinetic data was described in the reaction rate of pseudo-second-order model. Thermodynamic parameters explain the adsorption and the process was favorable exothermic nature.

\section{References}

1- Ong, S., Seng, C. and Lim, P., Kinetics of adsorption of $\mathrm{Cu}$ (II) and Cd (II) from aqueous solution on rice husk and modified rice husk. Electronic J. Environ. Agric. Food Chem., 1764177(2007).

2-Marais Barros, A. J., Prasad, S., Duarte Leite, V. and Gouveia Souza, A., The process of biosorption of heavy metals in bioreactors loaded with sanitary sewage sludge. Braz. J. Chem.Eng., 23, 153-162 (2006).

3- Unlü, N. and Ersoz, M., J. Hazard.Mater., Adsorption characteristics of heavy metal ions onto low cost biopolymeric sorbent from aqueous solution. 136, No. 2, 272-280 (2006).

4- Gupta, V. K., Jain, C. K., Ali, I., Shamra, M. and Saini, V. K., Removal of Cadmium and Nickel from wastewater using bagasse fly ash-a sugar industry waste. Water Resource., 37, 40384044 (2003).

5- Shukla, S. S., Yu, L. J., Dorris, K.L. and Shukla, A., Removal of Nickel from aqueous solutions by sawdust. J. Hazard. Mater., 121, 243246 (2005).

6- Hosterman, J.W. and S.H. Patterson. 1992. Bentonite and Fuller's earth resources of the United States. U.S. Geological Survey Professional Pa per 1522. United States
Government Printing Office, Washington D.C., USA.

7- Malkoc, E. and Nuhoglu, Y., Investigation of Nickel (II) removal from aqueous solutions using tea factory waste. J. Hazard. Mater., 127, 120-128 (2005).

8-Mohammed Jaafar Ali Al-atabe, Ahmed Alaa, . Isotherm and Kinetics studies, Adsorption of Chromium(III)Ions from Wastewater Using Cane Papyrus. Themed Section: Engineering and Technology |Volume3| Issue 6 | Print ISSN: 23951990 Online ISSN : 2017 IJSRSET 2394- 4099.

9- Padmavathy, V., Vasudevan, P. and Dhingra, S. C., Biosorption of Nickel(II) ions on Baker's yeast. Process Biochem., 38, 1389-1395(2003).

10-Srivastava, V. C., Mall, I. D. and Mishra I. M., Competitive adsorption of Cadmium(II) and Nickel(II) from aqueous solution onto rice hush ash. Chem. Eng. Process 48, 370-379,(2009).

11- Langmuir I (1916) The constitution and fundamental properties of solid and liquids. J Am Chem Soc 38:2221-2295, (76 pages).

12- Freundlich HMF (1906) Over the adsorption in solution. J Phys Chem57:385-471,(87 pages).

13-Langmuir, I., The adsorption of gases on plane surfaces of glass, mica and platinum. J. Am. Chem. Soc.40,1361-1403 (1918).

14- Nwabanne, J. T. and Ibbokwe, P. K., Kinetics and equilibrium modeling of Nickel adsorption by cassava peel. J. Eng. Applied Sci., 3, 829-834 (2008).

15-Ho, Y. S. and McKay, G., Pseudo-secondorder model for sorption processes. Process Biochem., 34, 451-465 (1999).

16- Wen, D., Ho, Y. S. and Tang, X., Comparative sorption kinetic studies of ammonium onto zeolite. J.Hazard. Mater., B133, 252-256 (2006).

17- Lagergren, S., Zur theorie der sogenanntan adsorption gloster stoffe. Sven. Vetenskapsakademiens Handl., 24, 1-39(1989).

18- Do, D. D., Adsorption Analysis: Equilibria and Kinetics. Imperial College Press, London, (1998).

19- Villaescusa, I., Fiola, N., Martinez,M., Miralles, N., Pochc., J. and Serarolsc, J., Removal of Copper and Nickel ions from aqueous solutions by grape stalks wastes. Water Res. 38, 992-1002 (2004). 


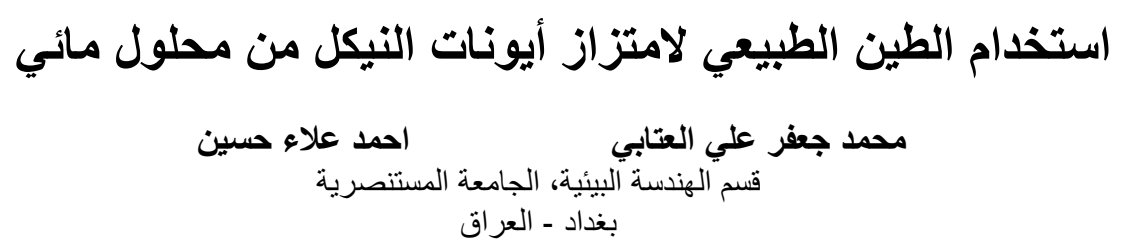

الخلاصة

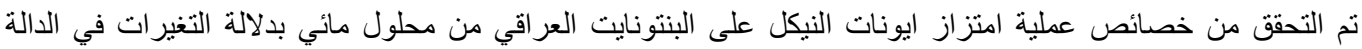

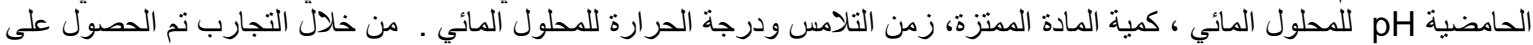

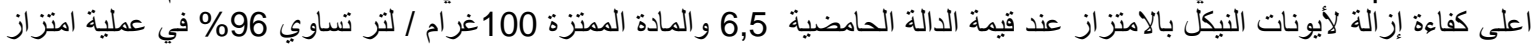

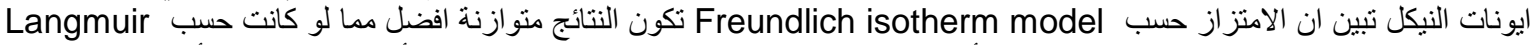
isotherm model

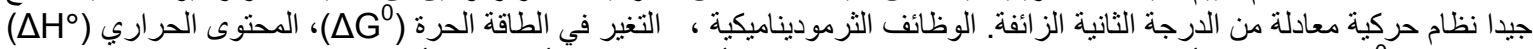

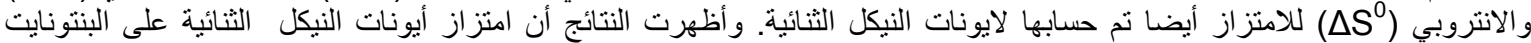
العر اقي ممكن ويكون التفاعل باعث للحرارة في 20-50 درجة مئوية 